\title{
FUNGSI PENGEMBANGAN KARIR DALAM MENINGKATKAN KINERJA PEGAWAI DI KECAMATAN BOGOR UTARA
}

\section{CAREER DEVELOPMENT FUNCTION IN IMPROVING THE PERFORMANCE OF EMPLOYEES IN KECAMATAN BOGOR UTARA}

\author{
Rafiek Firmansyah ${ }^{1 a}$ Rita Rahmawati2 Irma Purnamasari $^{3}$ \\ 1Jurusan Ilmu Administrasi Negara Fakultas Ilmu Sosial dan Ilmu Politik Universitas Djuanda, Jl. Tol \\ Ciawi No. 1, Kotak Pos 35 Bogor 16770. \\ ${ }^{2}$ Jurusan Ilmu Administrasi Negara Fakultas Ilmu Sosial dan Ilmu Politik Universitas Djuanda, Jl. Tol \\ Ciawi No. 1, Kotak Pos 35 Bogor 16770 \\ 3Jurusan Ilmu Administrasi Negara Fakultas Ilmu Sosial dan Ilmu Politik Universitas Djuanda, Jl. Tol \\ Ciawi No. 1, Kotak Pos 35 Bogor 16770. \\ aKorespondensi: R. Akhmad Munjin, Tel. 081329630051
}

(Diterima oleh Dewan Redaksi: 01-02-2015)

(Dipublikasikan oleh Dewan Redaksi: 01-05-2015)

\begin{abstract}
Organization, employee performance lies in the human factor (the members or employees) who carry out activities to achieve the goals of the organization itself. Employee performance is a picture of the employees who reflect the expertise, skills and abilities in addition to the employee, employee performance also reflects the willingness to work with passion. Theoretical framework is built by connecting the independent variable $(\mathrm{X})$ development of a career with the dependent variable ( $\mathrm{Y}$ ) databases must address satisfying employees, the relationship between variables is described in the context of career development model of Edwin B.Flipo while the performance of employees described by Simamora, based on the theoretical framework, the operational independent variable $(\mathrm{X})$ is a career development consists of six dimensions, namely: (1) the pattern and sequence of career development, (2) coordination of career development, (3) timeliness, (4) participation in career development, (5) means and infrastructure in career development, (6) the benefits of career development, employee performance while the dependent variable consists of four dimensions, namely: (1) creativity, (2) the ability of analysis and choose an alternative, (3) learning process, (4) problem solving. This study aims to determine the implementation of career development in improving the performance of employees in the District of North Bogor. The method used in this research is descriptive analysis method, which is a problem-solving procedure is investigated by using a state file subject or the object of research is happening right now based on factors that viewed the field as it should or used to describe a fact or a specific population in a systematic character, actual and fast and using the formula Weight Mean Score (WMS). Employee population is the object of observation as much as 42 people, and to determine the sample size formula used Yamane, limiting the number of samples to 31 people. Conclusions obtained from this calculation results show that the function of Career Development in Improving Performance in the District of North Bogor good interpretive criteria, even so the interview stated that there are deficiencies to be corrected.
\end{abstract}

Key words: Carier, Performance, Merit System 


\begin{abstract}
ABSTRAK
Penelitian ini bertujuan untuk mengetahui sejauh mana pelaksanaan pengembangan karier dalam meningkatkan kinerja pegawai di Kecamatan Bogor Utara, faktor-faktor yang mendukung dan menghambat pengembangan karier dan upaya-upaya mengatasinya.Metode yang digunakan dalam penelitian ini adalah metode deskriptif analisis, yaitu suatu prosedur pemecahan masalah yang diselidiki dengan menggunakan berkas keadaan subjek atau objek penelitian yang terjadi sekarang berdasarkan faktor-faktor yang dilihat dilapangan sebagaimana mestinya atau digunakan untuk melukiskan fakta atau karakter populasi tertentu secara sistematis, aktual dan cepat dan menggunakan rumus Weight Mean Score (WMS). Populasi pegawai yang menjadi objek pengamatan sebanyak 42 orang dan untuk menentukan besaran sampel dipergunakan rumus Yamane sehingga jumlah sampel menjadi 32 orang. Hasil penelitian ini menunjukan bahwa Fungsi Pengembangan Karier dalam Meningkatkan Kinerja di Kecamatan Bogor Utara kriteria penafsiran baik, sekalipun demikian hasil wawancara menyatakan bahwa masih terdapat kekurangan yang harus diperbaiki. Kesimpulan dari penelitian ini bahwa secara umum pengembangan Karier di Kecamatan Bogor Utara sudah berjalan dengan baik tetapi hasil wawancara masih terdapat kekurangan yang harus diperbaiki Saran dari penulis agar di Kantor Kecamatan Bogor Utara menerapkan Merit System dalam penempatan pegawai dan memberikan kesempatan yang seluas-luasnya kepada pegawai dalam pengembangan kariernya.

Kata kunci: Pengembangan karir, Kinerja, sistem merit.
\end{abstract}

Rafiek, 2015. Fungsi Pengembangan Karir dalam Meningkatkan Kinerja Pegawai di Kecamatan Bogor Utara. 


\section{PENDAHULUAN}

Kecamatan merupakan kepanjangan tangan dari pemerintahan kota atau kabupaten, kecamatan memiliki tugas pokok adalah melaksanakan sebagian urusan pemerintahan yang dilimpahkan Walikota untuk menangani sebagian urusan otonomi daerah dan tugas pemerintahan lainnya berdasarkan ketentuan peraturan perundang-undangan, dengan fungsi Kecamatan.

- Penyusunan rencana dan program kerja kecamatan.

- Perumusan dan penyusunan kebijakan teknis kecamatan.

- Penyelenggaraan tugas urusan pemerintahan.

Dalam menjalankan tugas pokok dan fungsi tersebut sangat tergantung dari kinerja pegawainya.

Kinerja pegawai terletak pada faktor manusia (para anggota atau pegawainya) selaku pelaksana kegiatan untuk mencapai tujuan organisasi itu sendiri. Faktor manusia mempunyai peranan yang sangat dominan dalam menentukan berhasil tidaknya kegiatan organisasi dalam mewujudkan tujuannya.

Kinerja pegawai merupakan gambaran hasil pegawai yang mencerminkan keahlian, ketrampilan dan kemampuan pegawai selain itu, kinerja pegawai tersebut juga mencerminkan kesedian bekerja dengan penuh semangat.

Namun masih banyak pegawai pada tingkat kecamatan yang belum menunjukan kinerja terbaiknya, contohnya pada Kecamatan Bogor Utara Kota Bogor dengan kepadatan penduduk $\mathbf{8 3}$ jiwa/Ha terdiri dari $\mathbf{8}$ Kelurahan, 108 RW dan 527 RT dengan luas wilayah 1.772 Ha. masih menunjukan bahwa kinerja pegawai rendah, hal ini terlihat dari indikator capaian pekerjaan Seksi-seksi yang ada di kantor kecamatan Bogor Utara yang belum memenuhi target.

Rendahnya kinerja tersebut diduga karena kurangnya pengembangan karier yang baik yang dibuat oleh pegawai yang bersangkutan, atasan langsung /Camat, maupun pejabat dari satuan kerja pengelola sumber daya manusia (SDM) dalam organisasi/BKPP.

Pengembangan karier pegawai berkaitan dengan usaha untuk memajukan pegawai dengan tujuan membantu pegawai dalam meningkatkan kemampuan pengetahuan dan kecakapan pegawai.

Namun selama ini hasil pengamatan sementara di Kecamatan Bogor Utara menunjukan bahwa pengembangan karier belum efektif hal ini terlihat dari indikator:

- Masih adanya ketidak sesuaian latar belakang pendidikan dengan pegawai yang menduduki jabatan tertentu contohnya : Lulusan Sarjana Pendidikan (S.Pd) memegang jabatan Lurah yang seharusnya jadi seorang Guru/Pendidik, Lulusan Sarjana Agama (S.Ag) menjadi PPLKB dan adapula lulusan STPDN dengan gelar STTP menjabat Kasi Ekonomi yang lebih cocok jadi Kasi Pemerintahan.

- Masih adanya yang memangku jabatan tertentu akan tetapi golongan/pangkatnya belum cukup memadai, misalnya jabatan diduduki oleh orang dengan golongan II-d padahal seharusnya dengan golongan III-a hal ini terjadi karena kurangnya perencanaan karier pegawai, tidak semua penempatan pegawai didasarkan atas merit system yaitu pegawai memperoleh kesempatan untuk mengembangkan karier karena pegawai tersebut berprestasi, atau dengan kata lain adanya kesesuaian antara kecakapan yang dimiliki seorang pegawai dengan jabatan yang dipercayakan kepadanya, meliputi tingkat pendidikan formal, tingkat pendidikan non formal/diklatpim, pendidikan dan latihan teknis, tingkat pengalaman kerja dan tingkat penguasaan tugas dan pekerjaan.

Kebijakan pengembangan karier seperti promosi jabatan belum sepenuhnya menggunakan merit system, melainkan masih ada praktek-praktek spoils system .

Diketahui bahwa di Kecamatan Bogor Utara masih ada sejumlah masalah yang berkaitan dengan kinerja pegawai.

Kinerja pegawai dinilai belum optimal, hal ini dapat dilihat dari pencapaian target belum $100 \%$ tercapai, karena kurangnya 
kreatifitas pegawai, kemampuan menyelesaikan masalah dan kurangnya kemampuan analisis.

Kurang optimalnya kinerja tersebut disebabkan karena kurangnya fungsi pengembangan karier, hal ini terlihat dari masih diterapkannya pendekatan spoils system dalam hal promosi atau penempatan jabatan, kesempatan memperoleh pendidikan lanjutan / pelatihan.

\section{MATERI DAN METODE}

Mulai Dalam penelitian ini adalah metode deskriptif analisis, yaitu suatu prosedur pemecahan masalah yang diselidiki dengan menggunakan berkas keadaan subjek atau objek penelitian yang terjadi sekarang berdasarkan faktor-faktor yang dilihat dilapangan sebagaimana mestinya atau digunakan untuk melukiskan fakta atau karakter populasi tertentu secara sistematis, aktual dan cepat.

Populasi adalah wilayah generalisasi yang terdiri atas objek/subjek yang mempunyai kwalitas dan karakteristik tertentu yang ditetapkan oleh peneliti untuk dipelajari dan kemudian ditarik kesimpulannya. Populasi dalam penelitian ini adalah semua karyawan Kecamatan Bogor Utara Kota Bogor berjumlah 41 orang.

Sampel adalah bagian dari jumlah karakteristik yang dimiliki oleh populasi tersebut dan sampel yang tergolong kedalam proporsional stratification random sampling atau proportionate stratified random sampling. Hal ini disebabkan populasi mempunyai anggota atau unsur yang tidak homogen dan berstrata secara proporsional, Sugiyono ( 2009 :93 ).

Populasi yang terdapat di Kamatan Bogor Utara adalah 41, untuk menemukan sampel yang sesuai dengan keterangan dalam tabel dengan tingkat kesalahan $5 \%$ atau tingkat kepercayaan terhadap pupulasi sebesar $95 \%$, maka digunakan rumus Yamane, yaitu :

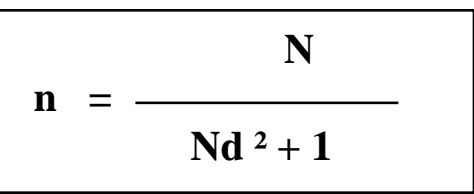

Keterangan :

\author{
n : Jumlah sampel \\ $\mathbf{N}$ : Ukuran populasi \\ d : Presisi ( perkiraan kesalahan \\ yang diperkirakan yaitu 0,1 ) \\ Sumber : Hasan, Iqbal ( 2002 : \\ 26) \\ $\mathrm{n}=\frac{\mathrm{N}}{\mathrm{N} \mathrm{d}^{2}+1}$
}

Nilai 29,07 dibulatkan menjadi 29.

Jadi, nilai 29 merupakan jumlah sampel yang akan diambil dalam penelitian di Kantor Kecamatan Bogor Utara Kota Bogor

Untuk mendapatkan jumah sampel per sub populasi dilakukan perhitungan menggunakan rumus metode alokasi proporsional menurut Nazir M.(1998:365). yaitu :

$$
\mathrm{ni}=\frac{\mathrm{Ni}}{\mathrm{N}} \times \mathrm{n}
$$

Dimana :

ni $=$ ukuran sampel yang diambil dari stratum ke - i

$\mathrm{Ni}=$ ukuran populasi stratum $\mathrm{ke}-\mathrm{i}$

$\mathrm{N}=$ ukuran populasi

$\mathrm{n}=$ ukuran sampel yang diambil

Dengan kata lain bahwa :

ni $=$ adalah nilai sampel yang dicari dari tiap sub populasi

$\mathrm{Ni}=$ jumlah tiap sub populasi

$\mathrm{N}=41$

$\mathrm{n}=29$ (yang merupakan ukuran sampel yang telah dihitung melalui tingkat kesalahan $5 \%$ dan kepercayaan $95 \%$ ).

Berikut ini perhitungan tiap populasi :

Tabel Sampel ( proportionate stratified random sampling )

\begin{tabular}{|c|c|c|c|}
\hline No. & Posisi & Populasi & Sampel \\
\hline 1 & $\begin{array}{l}\text { Sekretaris } \\
\text { Camat }\end{array}$ & 1 & 1 \\
\hline 2 & $\begin{array}{l}\text { Subag umum } \\
\text { dan } \\
\text { Kepegawaian }\end{array}$ & 5 & 4 \\
\hline 3 & $\begin{array}{l}\text { Subag } \\
\text { Keuangan }\end{array}$ & 5 & 4 \\
\hline 4 & $\begin{array}{l}\text { Seksi } \\
\text { Pemerintahan }\end{array}$ & 7 & 5 \\
\hline
\end{tabular}




\begin{tabular}{llll}
\hline 5 & Seksi Dalbang & 5 & 4 \\
6 & Seksi & 5 & 4 \\
& Kemasyarakatan & & \\
7 & Seksi & 5 & 4 \\
& Perekonomian & & \\
8 & Seksi Trantib & 8 & 6 \\
& Jumlah & $\mathbf{4 1}$ & $\mathbf{3 2}$ \\
\hline
\end{tabular}

Sumber : Kec.Bogor Utara

Tabel Klasifikasi Jawaban Skala Likert

\begin{tabular}{ccc}
\hline Jawaban & Klasifikasi & Skor \\
A & Setuju/selalu/baik & 3 \\
B & $\begin{array}{c}\text { CukupSetuju/kadang- } \\
\text { kadang/cukup baik }\end{array}$ & 2 \\
C & $\begin{array}{c}\text { Tidak Setuju/tidak } \\
\text { selalu/tidak baik }\end{array}$ & 1 \\
\hline
\end{tabular}

Tehnik analisa data dalam penelitian ini menggunakan perhitungan Weight means Score (WMS) yaitu untuk setiap item pertanyaan.

Adapun rumus Weight means Score (WMS) sebagai berikut :

$$
\mathbf{M}=\sum \frac{f(x)}{n}
$$

Keterangan:

$\mathbf{M}=$ Perolehan angka kriteria penafsiran

$\boldsymbol{f}=$ Frekuensi jawaban

$\mathbf{x}=$ Pembobotan (skala nilai)

$\sum=$ Penjumlahan

$\mathbf{n}=$ Jumlah seluruh jawaban responden

Siregar, Bakrie (1993:35)

Hasil dari perhitungan WMS ini dikonsultasikan pada tabel kriteria penelitian sebagai berikut :

\begin{tabular}{ccc} 
& Tabel Tabel Kriteria Penilaian \\
\hline No & Kriteria Skor & Kriteria \\
& Jawaban & Penilaian \\
1 & $1,00-1,66$ & Tidak baik \\
2 & $1,67-2,33$ & Sedang \\
3 & $2,34-3,00$ & Baik \\
\hline
\end{tabular}

\section{HASIL DAN PEMBAHASAN}

Hasil penelitian, Kecamatan Bogor Utara adalah salah satu Kecamatan dalam lingkup Kota Bogor, dasar hukum mengenai penetapan wilayah Kecamatan Bogor Utara dan berdirinya sebagai perangkat daerah Pemda Kota Bogor ditetapkan berdasarkan
Perda Kota Bogor Nomor 3 Tahun 2010 tentang Organisasi Perangkat Daerah. Lembaga ini dikepalai oleh seorang Camat dengan Eselon III A yang membawahi seorang Sekretaris Camat dengan Eselon III B dan 5 (lima) orang Kepala Seksi yang memiliki Eselon IV A dan 2 (dua) Kepala Sub Bagian yang memiliki Eselon IV B, berdasarkan Peraturan Pemerintah nomor 2 Tahun 1995 dan Inmendagri Nomor 30 Tahun 1995 tanggal 24 Agustus 1995 Tentang Perubahan batas wilayah Kotamadya Bogor dan Kabupaten Bogor, luas wilayah 1.772 Ha, yang secara administratif terbagi dalam 8 Kelurahan, 108 Rw, dan 527 Rt.

Berdasarkan data-data terakhir, jumlah penduduk Kecamatan Bogor Utara sampai dengan Desember 2011 sebanyak 37.859 Kepala Keluarga terdiri dari $\mathbf{1 5 4 . 2 2 2}$ jiwa dengan perincian sebagai berikut :

- Laki-laki : 79.038 Jiwa

- Perempuan : $\mathbf{7 5 . 1 8 4}$ Jiwa

Jumlah 154.222 Jiwa

Warga Negara Asing

$\begin{array}{ll}\text { - Laki-laki : } & 9 \text { Jiwa } \\ \text { - Perempuan : } & 2 \text { Jiwa } \\ \text { Jumlah } & \mathbf{1 1} \text { Jiwa }\end{array}$

\section{Keadaan Pegawai Kantor Kecamatan} Bogor Utara

a. Keadaan Kantor Kecamatan Bogor Utara berdasarkan golongan

Tabel Komposisi Pegawai Kantor Kecamatan Bogor Utara BerdasarkanGolongan

\begin{tabular}{|c|c|c|c|}
\hline No & $\begin{array}{c}\text { Jenis } \\
\text { Golongan }\end{array}$ & Pangkat & $\mathbf{J m l}$ \\
\hline 1. & IV b & Pembina Tk I & 1 \\
\hline 2. & IV a & Pembina & 1 \\
\hline 3. & III b & $\begin{array}{l}\text { Penata Muda } \\
\text { TK I }\end{array}$ & 7 \\
\hline 4. & III a & Penata Muda & 5 \\
\hline 5. & II d & $\begin{array}{l}\text { Penata Muda } \\
\text { TK I }\end{array}$ & 5 \\
\hline 6. & II c & Pengatur & 6 \\
\hline 7. & II b & Pengatur TK I & 7 \\
\hline 8. & II a & $\begin{array}{l}\text { Juru Muda } \\
\text { lah }\end{array}$ & $\begin{array}{c}9 \\
41\end{array}$ \\
\hline
\end{tabular}


TABEL Jumlah Pegawai berdasarkan Jenis Pendidikan

\begin{tabular}{clc}
\hline No & Jenis Pendidikan & Jumlah \\
1 & Sarjana/S 2 & 1 \\
2 & Sarjana/S 1 & 6 \\
3 & Akademi & 4 \\
4 & SMU & 30 \\
& Jumlah & 41 \\
\hline
\end{tabular}

Utara

Sumber : Data Kantor Kecamatan Bogor

\section{Struktur Organisasi Kecamatan Bogor Utara}

Sebagai pelaksanaan pengorganisasian pada Kantor Kecamatan Bogor Utara diatur dengan jenjang hirarki yang sistematis dalam struktur organisasi. Adapun struktur organisasi di Kantor Kecamatan Bogor Utara adalah berdasarkan Keputusan Menteri Dalam Negeri No. 83 tahun 1984, dengan susunan sebagai berikut : Kepala Wilayah Kecamatan (Camat) sebagai pemimpin tertinggi di wilayahnya. Dalam melaksanakan tugasnya sehari-hari Camat dibantu oleh para stafnya yang terdiri dari Sekretaris Kecamatan yang membawahi Kasubag Umum-kepegawain dan Kasubag Keuangan, Kasi. Pemerintahan, Kasi. Pengendalian Pembangunan, Kasi. Kemasyarakatan, Kasi. Perekonomian dan Kasi. Ketentraman-Ketertiban.

Untuk menjalankan tugas guna tercapainya tujuan organisasi Kantor Kecamatan Bogor Utara, maka fungsi Kepala Wilayah sebagai Wakil Pemerintah Pusat dan Penguasa Tunggal dalam arti menjalankan pimpinan pemerintahan, mengkoordinasikan pembangunan dan membina kehidupan masyarakat di segala bidang haruslah dijalankan secara sistematis dan menyeluruh mengingat luasnya tugas dan tanggung jawab Camat sebagai pemimpin wilayah.

Untuk mengetahui sejauh mana fungsi pengembangan karier dalam meningkatkan kinerja pegawai Kecamatan Bogor Utara, maka penulis menyebarkan angket sebanyak 32 angket kepada pegawai kecamatan, adapun tujuannya adalah untuk mendapatkan data yang kongkrit, Tanggapan tersebut disajikan dalam bentuk tabulasi berupa pernyataan terstruktur dengan didasarkan kepada indikator dari pengembangan karier dan kinerja termasuk hasil analisis statistiknya dipaparkan secara terperinci dalam bagian ini.

Tabel Rekapitulasi Pengembangan Karier

\begin{tabular}{|c|c|c|c|}
\hline Dimensi & Indikator & $\begin{array}{c}\text { Angka } \\
\text { Penafsir } \\
\text { an }\end{array}$ & $\begin{array}{l}\text { Kriter } \\
\text { ia } \\
\text { Penil } \\
\text { aian }\end{array}$ \\
\hline $\begin{array}{l}\text { 1.Pola dan } \\
\text { alur } \\
\text { pengemba } \\
\text { ngan karier }\end{array}$ & $\begin{array}{l}\text { Pola kenaikan } \\
\text { pangkat secara } \\
\text { reguler/pendid } \\
\text { ikan guna } \\
\text { menunjang } \\
\text { pengembangan } \\
\text { karier }\end{array}$ & 3,00 & Baik \\
\hline $\begin{array}{l}\text { 2.Koordinasi } \\
\text { dalam } \\
\text { pengembang } \\
\text { an karier. }\end{array}$ & $\begin{array}{l}\text { Koordinasi } \\
\text { dengan badan } \\
\text { terkait yaitu } \\
\text { BKPP/TU }\end{array}$ & 3,00 & Baik \\
\hline $\begin{array}{l}\text { 3. Ketepatan } \\
\text { waktu }\end{array}$ & $\begin{array}{l}\text { Ketepatan } \\
\text { waktu dalam } \\
\text { pengurusan } \\
\text { kenaikan } \\
\text { pangkat } \\
\text { pegawai }\end{array}$ & 2,90 & Baik \\
\hline $\begin{array}{l}\text { 4.Partisipasi } \\
\text { dalam } \\
\text { pengembang } \\
\text { an karier. }\end{array}$ & $\begin{array}{l}\text { Pengembanga } \\
\mathrm{n} \text { karier } \\
\text { pegawai } \\
\text { berguna untuk } \\
\text { kemajuan } \\
\text { organisasi }\end{array}$ & 2,93 & Baik \\
\hline $\begin{array}{l}\text { 5.Sarana dan } \\
\text { Prasarana } \\
\text { dalam } \\
\text { pengembang } \\
\text { an karier. }\end{array}$ & $\begin{array}{l}\text { Adanya } \\
\text { bantuan } \\
\text { belajar, } \\
\text { pelatihan dan } \\
\text { ijin belajar ( } \\
\text { kebutuhan - } \\
\text { pegawai ) dari } \\
\text { BKPP/TU. }\end{array}$ & 2,96 & Baik \\
\hline $\begin{array}{l}\text { 6.Manfaat } \\
\text { Pengembang } \\
\text { an Karier. }\end{array}$ & $\begin{array}{l}\text { Pengembanga } \\
\mathrm{n} \text { karier } \\
\text { menambah } \\
\text { wawasan dan } \\
\text { ilmu } \\
\text { pengetahuan. }\end{array}$ & 2,90 & Baik \\
\hline Jumlah & & $18: 6$ & \\
\hline \multicolumn{2}{|c|}{ Skor rata-rata } & 3 & Baik \\
\hline
\end{tabular}

Dari tabel rekapitulasi pengembangan karier di atas, diperoleh angka penafsiran $\mathbf{3}$ hal ini menunjukan penilaian baik artinya dapat disimpulkan bahwa pengembangan karier pegawai di Kantor Kecamatan Bogor Utara 
sudah berjalan dengan baik. Maka hal ini dapat diartikan bahwa pengembangan karier sudah berjalan dengan baik akan tetapi dari hasil wawancara menyatakan bahwa masih terdapat kekurangan-kekurangan dalam pelaksanaannya, antara lain, masih ada penempatan pegawai tidak berdasarkan merit system melainkan masih ada praktek-praktek spoils system.

\begin{tabular}{|c|c|c|c|}
\hline Dimensi & Indikator & $\begin{array}{c}\text { Angka } \\
\text { Penafsir } \\
\text { an }\end{array}$ & $\begin{array}{l}\text { Kriteria } \\
\text { Penilaian }\end{array}$ \\
\hline 1Kreatifitas & $\begin{array}{l}\text { Kemampuan } \\
\text { pegawai dalam } \\
\text { mengeluarkan } \\
\text { ide-ide baru } \\
\text { kearah } \\
\text { perkembangan } \\
\text { yang lebih } \\
\text { baik }\end{array}$ & 2,96 & Baik \\
\hline $\begin{array}{l}\text { 2Kemampuan } \\
\text { analisis dan } \\
\text { memilih } \\
\text { alternatif }\end{array}$ & $\begin{array}{l}\text { Kemampuan } \\
\text { pegawai untuk } \\
\text { menelaah } \\
\text { persoalan- } \\
\text { persoalan } \\
\text { dalam } \\
\text { pekerjaan } \\
\text { sekaligus } \\
\text { mengambil } \\
\text { inisiatif tanpa } \\
\text { arahan atasan. }\end{array}$ & 2,75 & Baik \\
\hline $\begin{array}{l}\text { 3.Learning } \\
\text { Process }\end{array}$ & $\begin{array}{c}\text { Kemampuan } \\
\text { pegawai dalam } \\
\text { menerima } \\
\text { sesuatu yang } \\
\text { baru }\end{array}$ & 2,81 & Baik \\
\hline $\begin{array}{r} \\
\text { Ju } \\
\text { Skor }\end{array}$ & $\begin{array}{l}\text { Kemampuan } \\
\text { pegawai dalam } \\
\text { Memecahkan } \\
\text { masalah sesuai } \\
\text { target dan } \\
\text { jadwal yang } \\
\text { telah } \\
\text { ditetapkan. } \\
\text { nlah } \\
\text { ta-rata }\end{array}$ & $\begin{array}{c}12: 4 \\
3\end{array}$ & Baik \\
\hline
\end{tabular}

Dari tabel rekapitulasi kinerjadi atas, diperoleh angka penafsiran $\mathbf{3}$ hal ini menunjukan penilaian baik artinya dapat disimpulkan bahwa kinerja pegawai Kecamatan Bogor Utara sudah berjalan dengan baik. Maka hal ini dapat diartikan bahwa kinerja pegawai sudah berjalan dengan baik akan tetapi dari hasil wawancara menyatakan bahwa masih terdapat kekurangan-kekurangan dalam pelaksanaannya, antara lain :

1. Masih terdapat pegawai yang masih malas melaksanakan apel pagi/siang.

2. Masih tedapat pegawai yang tidak melaksanakan pekerjaannya tidak tepat waktu.

3. Masih tedapat pegawai yang masa bodoh terhadap pekerjaannya.

Dari kedua tabel rekapitulasi di atas, diperoleh angka penafsiran $\mathbf{3}$ hal ini menunjukan penilaian baik artinya dapat disimpulkan bahwa kinerja sangat menunjang dalam pegembangan karier seorang pegawai, artinya apabila seorang pegawai tersebut kinerja baik akan cepat dipromosikan oleh atasannya otomatis kariernya akan cepat naik. Maka hal ini dapat diartikan bahwa fungsi pengembangan karier dalam meningkatkan kinerja pegawai sudah berjalan dengan baik akan tetapi dari hasil wawancara menyatakan bahwa masih terdapat kekurangan-kekurangan dalam pelaksanaannya, dan kekurangan itu dapat diperbaiki guna memberikan pelayanan prima kepada masyarakat karena pegawai negeri sipil tugasnya melayani masyarakat bukan dilayani masyarakat.

\section{KESIMPULAN DAN IMPLIKASI}

Setelah penulis mencoba untuk membahas dan menganalisa mengenai hasil penelitian yang penulis lakukan pada Bab-bab terdahulu, maka sampailah pada kesimpulan yang didasarkan pada identifikasi masalah dan hipotesis yang diajukan yaitu :

1. Berdasarkan penelitian yang lakukan pada Kantor Kecamatan Bogor Utara Kota Bogor, bahwa fungsi pengembangan karier dalam meningkatkan kinerja pegawai sudah berjalan dengan baik, itu bisa dilihat dengan menggunakan tabulasi frekuensi dihasilkan nilai $\mathbf{3}$ hal ini menunjukan kriteria penilaian baik, sekalipun demikian bedasarkan hasil wawancara menyatakan bawah masih terdapat kekurangan-kekurangan yang harus diperbaiki. 
2. Faktor

yang

mendukung

pengembangan karier :

a. Kepengurusan kepegawaian dilakukan secara teratur dan tertib sehingga pegawai dalam bekerja merasa nyaman karena kebutuhannya diperhatikan.

b. Diberikan ijin belajar dan dilakukan penyesuai ijasah dengan cara ujian penyesuaian ijasah dari 41 pegawai diberi ijin belajar sebanyak 3 orang dengan alasan aktifitas kantor tidak terganggu dan diberikan bantuan bagi pegawai yang sedang menyusun skripsi.

c. Mengikuti diklat-diklat yang diadakan oleh BKPP/TU untuk menambah wawasan dan pengalaman pegawai, contohnya :

- Diklatpim 4 bagi pegawai eselon IV jabatan Kepala Seksi

- Diklatpim 3 bagi pegawai eselon III jabatan Camat, Kepala Kantor

- Diklatpim 2 bagi pegawai eselon II jabatan Kepala Dinas, Kabag.

- Lemhanas : Walikota, Bupati .

\section{Faktor yang} pengembangan karier :

menghambat

a. Penempatan pegawai

tidak

berdasarkan merit system yaitu pegawai memperoleh kesempatan untuk mengembangkan karier karena pegawai tersebut berprestasi, atau dengan kata lain adanya kesesuaian antara kecakapan yang dimiliki seorang pegawai dengan jabatan yang dipercayakan kepadanya, meliputi tingkat pendidikan formal, tingkat pendidikan non formal/diklatpim, pendidikan dan latihan teknis, tingkat pengalaman kerja dan tingkat penguasaan tugas dan pekerjaan.

Kebijakan pengembangan karier seperti promosi jabatan belum sepenuhnya menggunakan merit system, melainkan masih ada praktekpraktek spoils system . misalnya ada jabatan struktural yang dipegang oleh orang dengan kompetensi yang tidak sesuai dengan pendidikan dan keahliannya, contoh :
- Jabatan Kasi. Trantib dijabat oleh lulusan Sarjana Hukum

- Jabatan Kasi. Dalbang dijabat oleh lulusan Sarjana Pendidikan

- Jabatan Kasi. Sosial dijabat oleh lulusan Sarjana Pemerintahan

- Jabatan Lurah dijabat oleh lulusan Sarjana Pendidikan

3. Usaha untuk mengatasi berbagai hambatan dalam pengembangan karier adalah sebagai berikut :

a. Penempatan pegawai harus berdasarkan merit system yaitu pegawai memperoleh kesempatan untuk mengembangkan karier karena pegawai tersebut berprestasi, atau dengan kata lain adanya kesesuaian antara kecakapan yang dimiliki seorang pegawai dengan jabatan yang dipercayakan kepadanya, meliputi tingkat pendidikan formal, tingkat pendidikan non formal/diklatpim, pendidikan dan latihan teknis, tingkat pengalaman kerja dan tingkat penguasaan tugas dan pekerjaan.

b. Menghilangkan praktek-praktek spoils system dengan cara menegakkan atau prosedur dan sangsi seperti :

- Penempatan pegawai berdasarkan prestasi/kecakapan.

- Menindak pelaku/oknum yang menjual belikan jabatan.

- Menindak pelaku/oknum yang menyalah gunakan jabatannya hanya untuk membantu rekan/keluarganya untuk menduduki jabatan tertentu.

- Menindak pelaku/oknum yang merekrut pegawai dengan cara suap.

Cara ini diharapkan bisa menghilangkan praktek-praktek Spoils System agar pemerintahan berjalan dengan baik.

\section{DAFTAR PUSTAKA}

Flippo, Edwin B., 1992 Manajemen Personalia, Jakarta, Erlangga. 
Handayaningrat, Soewarno, 1990 Pengantar Ilmu Administrasi dan Manajemen, Jakarta, Haji Mas Agung.

Manulang, 1987 Dasar-dasar Manajemen, Jakarta, Ghalia Indonesia.

Moekijat, 1986 Perencanaan dan Pengembangan Karier Pegawai, Bandung, PT. Remaja Rosdakarya.

Musanef, 1986Manajemen Kepegawaian di Indonesia, Jakarta, Gunung Agung.

Saksono, Slamet, 1987 Administrasi Kepegawaian, Jakarta, Konisius.

Siagian, Sondang P., 1985 Filsafat Administrasi, Jakarta, Gunung Agung. 1993 Kerangka Dasar Ilmu Administrasi, Jakarta, Pt. Rineka Cipta.

Zainun, Buchari, 1990Administrasi dan Manajemen Kepegawaian Pemerintah Negara Indonesia, Jakarta, Haji Mas Agung.

Bryant P. 1999. Biodiversity and Conservation. Retrieved October 4, 1999 from http://darwinbio.uci.edu/ sustain/bio6 5/Titlpage.html 